\author{
Magdalena Gapsa \\ Uniwersytet Łódzki \\ magdagapsa@onet.eu
}

\title{
MIEJSCE IMIENIA W KULTURZE BULGARSKIEJ ZWIĄZEK IMIENIA Z ŻYCIEM JEDNOSTKI I SPOŁECZNOŚCI
}

\section{Wprowadzenie}

Imię jest pierwszym i najważniejszym słowem w życiu każdego z nas [Walczak-Mikołajczakowa 2001], choć bardzo często przechodzimy obok niego dość obojętnie - przyjmujemy, że nadane przez rodziców nie ma większego znaczenia i wpływu na to, kim jesteśmy. To dzięki niemu można nas zidentyfikować (jak pisał Ludwik Jerzy Kern w wierszu $W$ imieniu imienia: „, $[.$.$] Imię potrzebne$ jest, by ktosia/ Odróżnić od drugiego ktosia. [...]" [Kern 2003]). Jest to również jedna z pierwszych informacji, których dowiaduje się o nas społeczeństwo, a na jego podstawie jesteśmy w stanie określić nie tylko np. wiek, narodowość, wiarę, ale także stopień wykształcenia czy status socjalny rodziny, z której dana osoba pochodzi. Dawniej miało ono za zadanie ochronić dziecko przed złymi mocami lub sprowadzić na nie pożądane cechy charakteru bądź cechy fizyczne [Walczak-Mikołajczakowa 2001]. Pisała o tym także Ewa Rzetelska-Feleszko:

Najstarszymi uchwyconymi przez naukę motywacjami nadawania imion były wróżby i życzenia wypowiadane podczas aktu nadania imienia dziecku, skierowane ku przyszłości nowo narodzonego: oby miał pomyślne życie i osiągnął pożądane, ważne społecznie cechy: uznanie i sławę, waleczność w obronie pokoju, ale i cnoty rodzinne. Równocześnie nadanie imienia „ochronnego”, tabuistycznego, motywowała wiara w jego magiczną moc. [...] [Rzetelska-Feleszko 2006].

Imię jest zatem nie tylko identyfikatorem, ale także wróżbą na całe życie i sposobem ochrony przed złymi mocami, jednakże w dzisiejszych czasach funkcje życzące lub chroniące nie są już najważniejszym czynnikiem przy wyborze imienia [Keber 2002]. 


\section{Definicja imienia}

Aby jednoznacznie określić, czym naprawdę jest imię, warto odwołać się do definicji słownikowych. W tym miejscu zacytuję i porównam definicje zawarte zarówno w polskich jak i bułgarskich słownikach.

Definicja imienia według Stownika języka polskiego brzmi następująco:

,

1. «osobiste, nierodowe miano człowieka»

2. «nazwa, nazwisko» $[\ldots]$

4. «każdy wyraz odmieniający się przez przypadki»" [SJP 2007].

Stownik języka butgarskiego (Речник на българския език) podaje następującą definicję:

\section{„ЙME $[\ldots]$}

1. Лично название на човек, дадено му при раждането; малко име. [...] // Разш. Лично, бащино и фамилно название на човек, лично и фамилно или само фамилно название. [...] // Допълнително название на човек; [...] // Фамилно название на човек, което обикновено се получава от съпруга. [...]

4. Название, дума, с която се обозначава, назовава нещо, за да се отличава от подобните му; наименование. [...]

8. [...] Граматическа категория изменяеми думи - названия на предмети, качества или количества [...]" [РБЕ 1990].

Definicja bułgarska została przytoczona z licznymi skróceniami, warto jednak podkreślić, że jest zdecydowanie bardziej rozbudowana od tej, którą podaje Stownik języka polskiego. W obu słownikach można jednak dostrzec liczne podobieństwa zarówno w konstrukcji (imię jako kategoria gramatyczna oba słowniki podają jako ostatnie znaczenie), jak i treści przytoczonego hasła. Zarówno w definicji polskiej jak i bułgarskiej przez imię rozumiane jest także nazwisko. Ciekawe jest natomiast czwarte znaczenie podawane przez Речник на българския език, które podkreśla funkcję identyfikacyjną, jaką pełni imię.

\section{Zarys osiągnięć onomastyki polskiej}

Badania onomastyczne mają w Polsce dość długą tradycję. Spośród największych i najbardziej uznanych badaczy polskich należy w tym miejscu przytoczyć takie nazwiska jak Witold Taszycki (badający głównie imiona nadawane w średniowieczu), Tadeusz Milewski (polskie i słowiańskie imiennictwo na tle porównawczym indoeuropejskim), Aleksandra Cieślikowa (historyczne i współczesne procesy kształtowania się nazw własnych, badania etymologiczne), Kazimierz Rymut (autor Stownika imion wspótcześnie w Polsce używanych) czy Maria Malec (związki nazw własnych ze zjawiskami kulturowymi) [Malec 2006]. Wymienić należy także Ewę Rzetelską-Feleszko, pod której redakcją ukazała się pierwsza w Polsce synteza onomastyczna pt. Polskie nazwy własne. Encyklopedia oraz dwutomowa encyklopedia Stowiańska onomastyka [Rzetelska-Feleszko 2002]. 


\section{Funkcja apotropaiczna imion}

Imiona mają (a może miały?) niezwykle silną, magiczną moc. Zawsze zawierają w sobie tajemnicze „coś”, czego już na początku ziemskiej wędrówki życzy się człowiekowi. Najogólniej tradycyjne imiona słowiańskie ze względu na funkcję dzielimy na życzące (wróżby, przynoszące pożądane cechy charakteru itp.) oraz chroniące (zapewniające ochronę przed złymi mocami, a w czasach chrześcijańskich także opiekę ze strony świętych patronów) [Walczak-Mikołajczakowa 2001], choć funkcja ochronna imion w dzisiejszych czasach nie jest obligatoryjna [Malec 2001]. W związku z powyższym bardzo częste jest zjawisko proprializacji, czyli przechodzenie nazw pospolitych w nazwy własne. Poniżej podano przykłady tego procesu, ponieważ jednak praca skupia się na związkach imion z kulturą, a nie na lingwistycznych zagadnieniach z nimi związanych, zjawisko to nie będzie szerzej omawiane.

Wśród bułgarskich imion życzących znajdziemy różne konstrukcje, które czasami mogą wydawać się dziwne. Przykłady imion przytaczam za Mariolą Walczak-Mikołajczakową [2010] natomiast ich znaczenia za Podręcznym słownikiem bułgarsko-polskim [Sławski 1987a i 1987b]. Imiona życzące, które wróżyły urodę, zdrowie i inne zalety najczęściej powstawały od nazw roślin, zwierząt, zjawisk przyrodniczych itp. Siłę i męstwo przynosiły imiona takie jak Пламен (płomień), Мечо (niedźwiedź), Вълк (lub inne utworzone od rdzenia vylk, czyli wilk), Камен (kamień) сzy Желязко (od żelaza), które jednocześnie przez zapewnienie dziecku tychże cech miały za zadanie chronić je w dalszym życiu (są to zatem imiona życząco-chroniące). Przykłady innych imion życzących, utworzonych od nazw roślin lub zjawisk przyrodniczych to: Невена (od nagietka), Цветан, Цветана (od kwiatu) сzу Незабравка (od niezapominajki), Малина (od maliny), Звездан (od gwiazdy), Златка czyli złota czy Зорница czyli jutrzenka. Imiona życzące mogły być tworzone także bezpośrednio od nazw pożądanych u dziecka cech zarówno fizycznych jak i psychicznych. Tutaj wymienić należy imiona takie jak Здравко (ten, który cieszy się zdrowiem), Младен (mtody), Драган (drogi), Рада, Радко (lud. rad, kontent, zadowolony), Весел, Веселина (wеsoty), Милена (mita, miłowana), Добра (dobra), Красна (piękna), Деян (pracowity, od scs. dějati, czynić [Bartula 2011]), Бойка (bojowa, dziarska, śmiała), czy Искрена (szczera). Imiona zapewniające urodę często tworzono od nazw kolorów, które dla Słowian Południowych były niejako symbolami piękna. Przykłady takich imion to: Румяна (rumiana), Бяла (od bieli) czy Mодра (modra). Mądrość miały na dziecko sprowadzić imiona typu Бистра (warto tutaj zwrócić uwagę na homonimię przymiotnika bystry, który oznacza mądrość, jednocześnie bystry może być np. potok) lub Искра oraz inne etymologicznie podobne. W późniejszym czasie pojawiły się także imiona utworzone od pojęć abstrakcyjnych, takie jak Дар (dar, talent), Любов (miłość), Надежда (nadzieja) czy Вяра (wiara).

Warto wspomnieć także o grupie imion chroniących. Aby ochronić dziecko przed brzydotą nadawano mu imię utworzone od przymiotnika грозен, сzyli brzydki; straszny. Miał to być znak dla złych mосy, że Грозен lub Грозана jest już wystarcza- 
jąco szpetnym człowiekiem i w związku z tym, na zasadzie kontrastu, zapewnić mu urodę. Żeńska forma tego imienia została z czasem przekształcona w formę Гроздана, która wywodząc się od rzeczownika грозде, czyli winogrono, miała zapewnić kobiecie płodność (imię chroniące stało się w ten sposób imieniem życzącym). Z czasem w całym południowosłowiańskim (i słowiańskim w ogóle) systemie antropomorficznym pojawiły się także imiona chrześcijańskie. Nadanie dziecku imienia świętego miało za zadanie zarówno powierzenie go opiece patrona jak i zapewnienie mu jego cech, stąd imiona chrześcijańskich świętych znajdują się na pograniczu imion chroniących i życzących, spełniając jednocześnie obie funkcje apotropaiczne. Z podobnych powodów cenione jest nazywanie dzieci (zwłaszcza chłopców) imionami chanów i carów (np. imię Ивайло znajduje się wśród 20 najczęściej występujących imion w Bułgarii, popularne są również imiona Крум сzу Асен).

\section{Najpopularniejsze imiona bulgarskie w roku 2017}

Tabela 1. Najczęstsze imiona bułgarskie (stan na rok 2017)

\begin{tabular}{|c|c|c|c|c|}
\hline \multirow{2}{*}{} & \multicolumn{2}{|c|}{ Mężczyźni } & \multicolumn{2}{c|}{ Kobiety } \\
\cline { 2 - 5 } & imię & liczba wystąpień & imię & liczba wystąpień \\
\hline 1 & Георги & 163109 & Мария & 114651 \\
\hline 2 & Иван & 154069 & Иванка & 58578 \\
\hline 3 & Димитьр & 120400 & Елена & 52714 \\
\hline 4 & Николай & 93396 & Йорданка & 37885 \\
\hline 5 & Петър & 72275 & Пенка & 30815 \\
\hline 6 & Христо & 58879 & Даниела & 30374 \\
\hline 7 & Александър & 58689 & Росица & 29476 \\
\hline 8 & Стефан & 51552 & Десислава & 29333 \\
\hline 10 & Йордан & 50091 & Петя & 29326 \\
\hline 11 & Васил & 48329 & Гергана & 28220 \\
\hline 12 & Тодор & 46488 & Марийка & 26469 \\
\hline 13 & Стоян & 46415 & Виолета & 26130 \\
\hline 14 & Атанас & 44670 & Маргарита & 25834 \\
\hline 15 & Ангел & 44391 & Виктория & 25724 \\
\hline 16 & Красимир & 44170 & Надежда & 24631 \\
\hline 17 & Пламен & 40618 & Силвия & 24590 \\
\hline 18 & Никола & 37446 & Емилия & 24341 \\
\hline 19 & Ивайло & 36134 & Румяна & 24275 \\
\hline 20 & Валентин & 33242 & Радка & 23912 \\
\hline $\mathbf{2 n y y y}$ & 33919 & Милена & 23026 \\
\hline
\end{tabular}

Źródło: Национален статистически институт. 
W chwili obecnej wśród 20 najpopularniejszych imion w Bułgarii imiona wymienione wcześniej są spotykane, jednak do imion najpopularniejszych należą imiona chrześcijańskie. Imiona, które możemy umownie nazwać „tradycyjnymi” są dużo popularniejsze wśród imion żeńskich. Wśród imion męskich znajdziemy imiona Стоян (да стои, да живее [Български именик]), Красимир (krzesi, budzi pokój lub ozdoba świata) oraz Пламен, wśród żeńskich - Росищa, Десислава (да намира слава, да постигне слава [Български именик]), Надежда, Румяна, Радка оraz Милена.

Do imion chrześcijańskich zaliczamy - męskie: Георги, Иван, Николай, Петър, Христо, Стефан, Йордан, Тодор, Ангел, Никола, żeńskie: Мария, Иванка, Йорданка, Пенка, Даниела, Петя, Гергана, Марийка. Liczne są również imiona pochodzenia greckiego, np. Димитър, Александър, Васил, Атанас wśród męskich і Елена oraz Маргарита wśród żeńskich. Popularne są również imiona łacińskie: Мартин, Валентин, Виктория, Силвия, Емилия oraz z innych języków jak Виолета (z francuskiego).

\section{Wpływ imienia na życie dziecka i rodziny}

Poprzez nadanie odpowiedniego imienia można było także wpływać na losy rodziny. W przypadku, kiedy rodzina zaczynała robić się zbyt liczna nadawano dzieciom imiona utworzone od słów związanych z końcem. Przykłady takich imion to: Краен, Крайна (krańcowy, skrajny, końcowy), Последен, Последна (ostatni), Запрян (od запирам czyli zatrzymywać, zamykać). W przypadku gdy małżeństwo chciało mieć dużo dzieci, pierworodne często było nazywane Първан (od първи, czyli pierwszy; lud. pierwotny, poczatkowy), co oznaczało, że pojawią się jeszcze następni członkowie rodziny. Za pomocą imienia próbowano wpływać także na płeć potomstwa. W sytuacji kiedy rodziły się same dziewczynki, rodzice zaś chcieli mieć syna, córki chrzczono imionami Дocma (od dość, dosyć) lub Спренка (od czasownika спирам, czyli zatrzymywać, wstrzymywać), co miało spowodować, że w danej rodzinie nie urodzi się już więcej dziewczynek.

Ważne jest również to, że aż do dnia chrztu imię dziecka objęte było tabu. Aby nie wywoływać niepotrzebnego zainteresowania ze strony złych mocy używano pewnego rodzaju określeń zastępczych. Najczęściej były one tworzone od charakterystycznych cech dziecka takich jak nagość (stąd голчo), czy moczenie pieluszek (stąd пикла). Imię dla dziecka wybierał ojciec chrzestny i aż do dnia chrztu trzymał je w tajemnicy, w szczególności przed matką dziecka, która będąc w okresie połogu pozostawała nieczysta. Jeśli nie powstrzymałaby się od zwracania się do dziecka po imieniu mogłoby to być przyczyną (w najlepszym wypadku) choroby dziecka a nawet prowadzić do jego śmierci, ponieważ wywołałoby to zainteresowanie dzieckiem ze strony złych mocy. Imię było ważne z jeszcze jednego powodu - człowiek bezimienny nie mógł być członkiem żadnej społeczności. Obrzęd nadania imienia był więc równoznaczny z uznaniem za pełnoprawnego członka danej grupy społecznej. 
W przypadku chorób lub innych nieszczęść trapiących rodzinę, aby uchronić następne dziecko można było spróbować oszukać złe moce przez zmianę imienia. Odbywała się wtedy „kradzież” dziecka. Kobieta przyjmująca poród wynosiła rano dziecko z jego domu i zostawiała na rozstaju dróg. Pierwsza osoba, która je znalazła miła prawo nadać mu nowe imię - zazwyczaj było to imię Найден lub Обретен, oba w terminologii ludowej oznaczające znaleziony. Pod takim imieniem złe moce nie mogły już człowieka rozpoznać, a co za tym idzie także wyrządzić mu zaplanowanej wcześniej krzywdy.

\section{Czynniki wpływające na wybór imienia}

Oczywiście w dzisiejszych czasach znaczenie imienia nie jest najważniejszym czynnikiem przy jego wyborze. Bardzo istotną rolę w tym procesie odgrywają trendy nazewnicze. Przyszli rodzice śledzą listy i rankingi najmodniejszych i najpopularniejszych imion z dwóch powodów - żeby znaleźć wśród nich inspirację i nadać dziecku imię modne w danym okresie lub wręcz odwrotnie - aby uniknąć nazwania swojego dziecka imieniem, które będzie częste wśród jego rówieśników. Szczególnie ważna w bułgarskiej kulturze jest tradycja nadawania dzieciom imion po przodkach, najczęściej dziadkach i babciach. Jest to o tyle ważne, że w ten sposób można symbolicznie przedłużyć własne życie - skoro nasze imię funkcjonuje, „żyje” w następnych pokoleniach, my żyjemy wraz z nim. Nadanie imienia po członku rodziny nazywa się подновяване на името, czyli odnawianiem imienia. Dziadkowie dbają o to, aby swoje imię przekazać wnukom jeszcze za życia. Ze względu na to, że zmniejszyła się liczba rodzących się dzieci, najczęściej wnucząt jest mniej, niż dziadków. Aby nikt nie czuł się pokrzywdzony i pominięty, a w związku z tym niejako skazany na niepamięć, wymyślono pewien sposób na nadanie jednemu dziecka imion więcej niż jednego z dziadków. Rodzice dziecka do dyspozycji mają cztery imiona. Aby uhonorować swoich rodziców, $\mathrm{z}$ ich imion wybiera się fragmenty - mogą to być całe sylaby lub tylko pojedyncze litery - które składa się w całość, tworzącą zupełnie nowe imię (jest ono zatem oryginalne i nowoczesne) i jednocześnie gloryfikujące starsze pokolenie. Przykładem takiej konstrukcji może być imię Велиденка - połączenie imion Велика і Младенка.

\section{Podsumowanie}

Podsumowując, kluczową funkcję apotropaiczną w życiu człowieka pełniło imię. Bez niego człowiek ani nie był chroniony przed demonami, zjawami i innymi złymi mocami, ani nie mógł stać się pełnoprawnym członkiem społeczności. Na zakończenie należy również zaznaczyć być może nieoczywisty, ale jednocześnie nierozerwalny związek między systemem imienniczym a kulturą danej społeczności. Pisał o tym już Tadeusz Milewski: 
Imiona osobowe tworzą system, który wyodrębniając się z całości języka pewnymi specyficznymi cechami, stanowi równocześnie część tradycji prawno-obyczajowej każdego społeczeństwa. Imiona, będąc tworami językowymi, są równocześnie środkiem orientacji w obrębie społeczeństwa, systemem klasyfikacji jego członków. W tych warunkach zachodzi niewątpliwy związek między imiennictwem osobowym a kulturą [...] [Milewski 1969].

Jak zaprezentowano powyżej, imiona to nie tylko identyfikatory członków danej społeczności. Imiona mają zdecydowanie głębsze znaczenie zarówno dla osoby, która dane imię nosi, ale także dla całej społeczności, w której taka osoba żyje. Z nadaniem imienia wiąże się (czy może niestety wiązało się) wiele tradycji, obrzędów i przesądów. $Z$ pozoru błahe, niewiele znaczące słowo mogło wpływać na wszelkie aspekty ludzkiego życia. Za Marią Malec [2001] zacytuję jeszcze:

O tym, jak ważne jest posiadanie imienia, świadczy m.in. obecne jeszcze w niektórych zakątkach obszaru słowiańskiego przeświadczenie, że dzieci urodzone martwe, „bezimienne”, nieochrzczone mają cechy demoniczne, cierpią, błąkają się po świecie, dopóki ktoś ich nie nazwie imieniem.

Ciekawostka na zakończenie - o tym, jak ważne jest nadanie oryginalnego imienia w każdej kulturze, nie tylko bułgarskiej, niech świadczy fakt, że w Szwajcarii istnieje firma Erfolgswelle (czyli fala sukcesu), która zajmuje się wymyślaniem oryginalnych i kreatywnych imion dla dzieci (informacja pochodzi z portalu dariknews.bg, dokładny adres strony internetowej podano w bibliografii w wykazie źródeł internetowych). Proces tworzenia imienia dla dziecka trwa około dwóch miesięcy, biorą w nim udział eksperci, historycy, thumacze, artyści itd. Imię musi być oczywiście dopasowane do kultury, z której pochodzą rodzice i w której dziecko będzie wychowywane, nie może wzbudzać negatywnych konotacji oraz musi być łatwe w wymowie i zapisie. Cena takiej usługi to jedyne 25000 euro...

\section{Bibliografia}

Bartula, C. (2011), Podstawowe wiadomości z gramatyki staro-cerkiewno-stowiańskiej na tle porównawczym, Wydawnictwo Naukowe PWN, Warszawa.

Gapsa, M. (2016), Nadprzyrodzone zagrożenia dla nowonarodzonego dziecka i sposoby ochrony noworodków - wierzenia butgarskie, „Noviny Slawia” nr 5, s. 15-21.

Keber, J. (2002), Rojstna imena, hišna imena, vzdevki, psevdonimi v Sloveniji, ,Jezikoslovni zapiski", nr 8 (2), s. 47-69.

Kern, L.J. (2003), Imiona nadwiślańskie, Wydawnictwo Literackie, Kraków.

Malec, M. (2001), Imię w polskiej antroponimii i kulturze, Wydawnictwo Naukowe PWN, Kraków.

Malec, M. (2006), Wkład krakowskiego językoznawstwa polonistycznego do nauki o imionach osobowych, „LingVaria”, nr 1 (1), s. 127-137.

Milewski, T. (1969), Indoeuropejskie imiona osobowe, Zakład Narodowy imienia Ossolińskich, Wrocław-Warszawa-Kraków.

Речник на българския език, m. 6, и-й (1990), red. К. Чолакова, Издателство на българска академия на науките, София.

Rzetelska-Feleszko, E. (2006), W świecie nazw własnych, Towarzystwo Naukowe Warszawskie, Warszawa-Kraków.

Sławski, F. (1987a), Podręczny słownik butgarsko-polski, t. 1, A-Повявам, Państwowe Wydawnictwo Wiedza Powszechna, Warszawa. 
Sławski, F. (1987b), Podręczny stownik bułgarsko-polski, t. 2, Повярвам-Ящен, Państwowe Wydawnictwo Wiedza Powszechna, Warszawa.

Słowiańska onomastyka, encyklopedia (2002), t. 1, red. E. Rzetelska-Feleszko, A. Cieślikowa, Towarzystwo Naukowe Warszawskie, Warszawa-Kraków.

Słownik Języka Polskiego (2007), t. 1, A-Ó, red. L. Drabik, E. Sobol, Wydawnictwo Naukowe PWN, Warszawa.

Walczak-Mikołajczakowa, M. (2001), Bałkańskie rytmy życia czyli o tradycji przechowanej w języ$k u$, Wydawnictwo „TUM”, Gniezno.

\section{Źródla internetowe}

Behind the Name, http://www.behindthename.com

Български именик, https://www.imenata.com

Имената в България 2017, http:/www.nsi.bg/sites/default/files/files/pressreleases/Names2017p. pdf (dostęp 25.02.2018).

Не кръщавайте децата си с двойни или екзотични имена, https://dariknews.bg/novini/komentar/ ne-kryshtavajte-decata-si-s-dvojni-ili-ekzotichni-imena-1581156 (dostęp 5.12.2017).

Gałkowski, A. (2012), Terminologia onomastyczna. Aktualizowana lista podstawowych haset terminologii onomastycznej $w$ języku polskim, http://onomastyka.uni.lodz.pl/strona-glowna/terminologia-polska (dostęp: 7.10.2018).

\section{Magdalena Gapsa}

\section{GIVEN NAME AND ITS PLACE IN BULGARIAN CUTURE}

\section{(Summary)}

The author analyzes the role of given name in Bulgarian culture and focuses on the role played by name in Bulgarian society. Detailed analysis has been subjected to the protective function of the name. The reader may refer to the traditional names used in Bulgaria, find out how they were created and what they mean, as well as how to affect the fate of the family by using proper name. The author also describes the importance of the name and the factors, that influence his choice. The article also presents statistics on the most popular Bulgarian names in 2017.

Key words: given names, Bulgaria, 2017 